\title{
Mechanical Impact in Disk Mill for Producing Controlled Rice Husk Particle Size by Changing Impactor Shapes and Disk Rotation Speeds
}

(Kesan Mekanikal di Kilang Cakera untuk Menghasilkan Saiz Zarah Sekam Padi Terkawal dengan Mengubah Bentuk Impak dan Kelajuan Putaran Cakera)

\author{
Asep Bayu Dani Nandiyanto*, Risti Ragadhita, Ajeng Sukmafitri, MuHammad Roil Bilad, MuHammad \\ AZIZ \& JUMRIL YUNAS
}

\begin{abstract}
The purpose of this study was to evaluate regulation of mechanical impact (i.e. impactor sizes and shapes) on triangle, cylinder, and cube as well as disk rotation speed (from 600 to $1500 \mathrm{rpm}$ ) in disk mill for controlling size-reduction process. As a model of size-reduced material, rice husk was selected. The study was done by evaluating the final milling product size, which was completed by the measurement of energy impact during the milling process. Experimental results showed that the product size was controllable in the range of between 50 and $1000 \mu \mathrm{m}$. The impactor sizes and shapes influenced the contact diameter and area of impactor for making more materials being collided, whereas disk rotation speed led to giving more collision number (between rice husk and impactor) and increasing impact from the collision (due to less time contact during collision). This study provides an important information, which can be further generalized in the use of milling process as a tool for materials size-reduction and mechanochemical process.
\end{abstract}

Keywords: Disk mill; education; impactor shapes; mechanical impact; milling process; particle size distribution

\section{ABSTRACT}

Tujuan kajian ini adalah untuk menilai peraturan ketetapan impak mekanikal (seperti ukuran dan bentuk impak) dalam segitiga, silinder dan kubus serta kelajuan putaran cakera (dari 600 hingga 1500 rpm) di kilang cakera untuk mengawal proses penurunan saiz. Sebagai model bahan saiz terkurang, sekam padi telah dipilih. Kajian ini dijalankan dengan menilai ukuran akhir produk yang dikisar dan disempurnakan dengan pengukuran kesan tenaga hentaman semasa proses pengisaran. Keputusan uji kaji menunjukkan bahawa ukuran produk dapat dikawal dalam lingkungan 50-1000 $\mu \mathrm{m}$. Saiz dan bentuk impak mempengaruhi diameter sentuhan dan luas kawasan pemukul kerana lebih banyak bahan berlanggar, sedangkan kelajuan putaran cakera menyebabkan lebih banyak bilangan pelanggaran (antara sekam padi dan impak) dan peningkatan jumlah impak daripada pelanggaran (disebabkan masa sentuhan yang singkat daripada pelanggaran). Kajian ini menyediakan maklumat yang penting dan dapat dikaji dengan lebih lanjut dalam proses pengisaran sebagai alat untuk pengurangan saiz bahan dan proses kimia mekanik.

Kata kunci: Bentuk impak; kilang cakera; pendidikan; proses penghancuran; sifat mekanikal; taburan saiz zarah

\section{INTRODUCTION}

Disk mill is one of the milling machines that can be used for reducing material size. This apparatus has been widely used in agriculture (Sasaki et al. 2016), mining (Amankwah et al. 2010), and chemical industries (Gorrasi \& Sorrentino 2015). In general, the reduction of size is needed for improving physicochemical properties to get added value of material (Yadav et al. 2012).

Disk mill is a combination of Hammer Mill and Roller Mill technologies. It is worked by applying punches and pressures in reducing sizes of materials (Ariwibowo et al. 2018). The advantages of disk mill are: The final size distribution is relatively homogenous, the milling process is not time-consuming, and the process can be done continuously (Uzun \& Durmuş 2016). Several studies have shown the successful of disk-milling process for reducing various materials, such as biomass (Womac et al. 2007), silicon (Odo et al. 2012), tungsten carbide (Rice et al. 2009), and kaolin (Meenakshi et al. 2008), as well as rocks and minerals (Jayasundara et al. 2010). Commercially, this apparatus is well-known as a flour milling machine for milling rice, corn, and cassava (Kumar et al. 2008). 
When using disk mill, some parameters should be considered to get the optimum process condition, including milling time, disk rotation speed, impactor size, operational conditions (i.e. temperature, moisture content, density, and roughness of material), as well as initial material size and input load (Li et al. 2018). However, studies on controlling mechanical impact by changing impactor shapes and disk rotation speed were not well-documented.

Our previous studies have reported the parameters effectively reducing particle size using the milling process (Dirgantari et al. 2019; Nandiyanto 2019; Nandiyanto et al. 2020, 2018a, 2018b, 2018c, 2017; Sukmafitri et al. 2020). Here, this study was focused on the investigation of controlling mechanical impact in the disk-milling apparatus for managing the final product size. To control the mechanical impact, impactor sizes, and shapes (i.e. triangle, cylinder, and cube), as well as disk rotation speed were varied, in which the results of these parameters were evaluated by observing the final product sizes. Regarding the number of impactors, different from commercial-typed disk-milling equipment, the present milling apparatus were attached only by three impactors on the disk to ensure the precise measurement of mechanical impact. Although the results of the present disk-milling apparatus (due to less number of impactors) are less than that of the commercial one, the effect of changing parameters on the number of mechanical impacts can be measured accurately.

As a model of a size-reduced material, rice husk was selected because this type of material is one of the tough materials, which cannot be easily destroyed. Experimental procedure was done by slowly putting the rice husk into the disk-milling apparatus. To ensure the mechanical impact during the disk-milling process, different from other continuous disk-milling process, the present milling process was set as the batch process. All materials were put in the beginning of the process, while the product was obtained continuously.

To analyze the particle size distribution of rice husk after the disk-milling process, the sieving method was used. The experimental results showed that the impactor shapes and the disk rotation speeds regulate the mechanical impact, confirmed by the great influence on changing collision profiles. Indeed, the change in the mechanical impact gave great impacts on the final particle size. The analysis was also confirmed using the measurement of energy consumption and the milling ability.

\section{THEORITICAL DISK MILL MECHANISM}

Figure 1 shows the illustration of milling process using a disk-milling apparatus. The principle of the disk-milling process in the particle size reduction is from the interaction of the materials and impactor. In short, the mechanism using the present disk-milling process (batch process) can be described in the following. When the disk-milling machine is turned on (Figure 1(a)), all materials that are put through the inlet holes fall towards the reactor. In the reactor, the size-reduction process occurs because the impactors that undergo rotation collide, hit, and push the materials to the reactor's wall (Figure 1(b)). The impactors continuously hit the materials, making more materials to collide the reactor's wall (Figure 1(c)). Then, the collided materials with the reactor's wall can get other interactions to other impactors (Figure 1(c)). The longer milling time

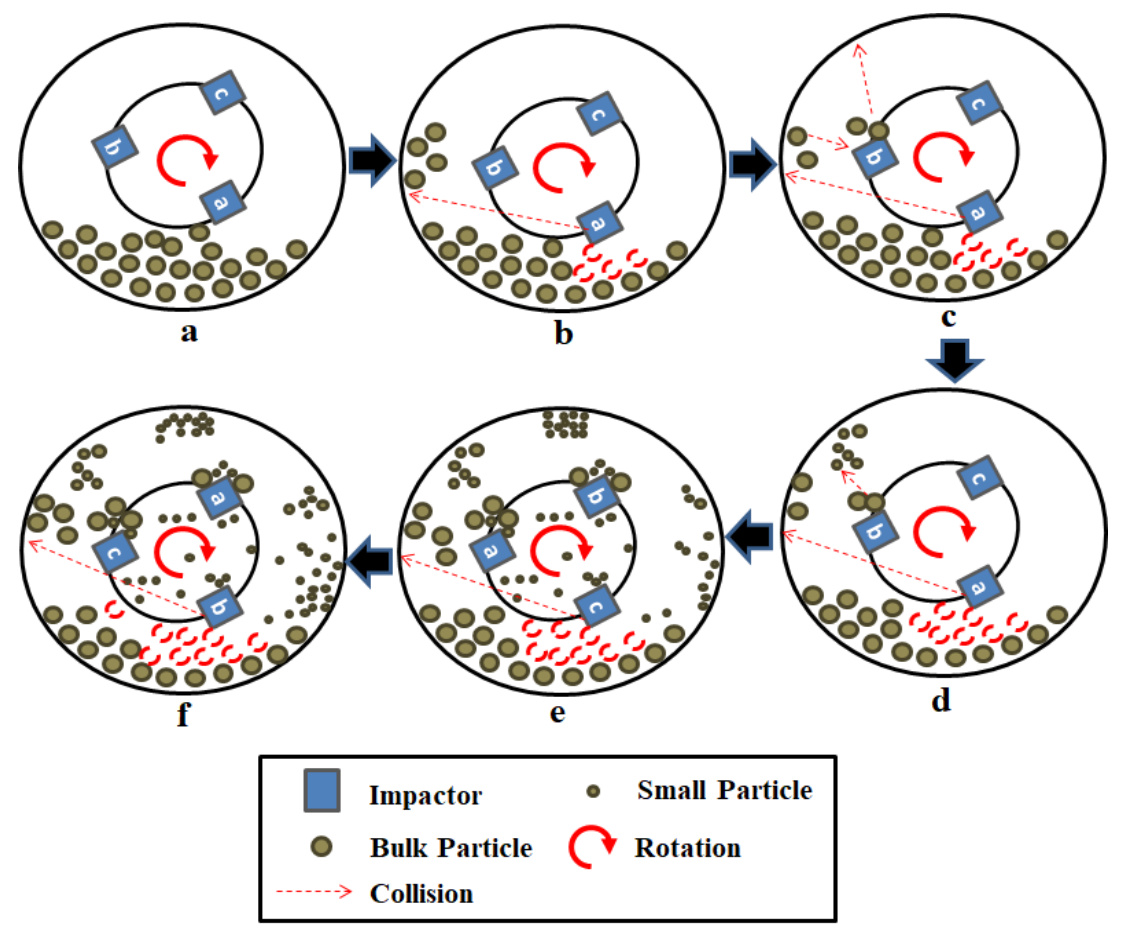

FIGURE 1. Illustration of material milling process using disk mill 


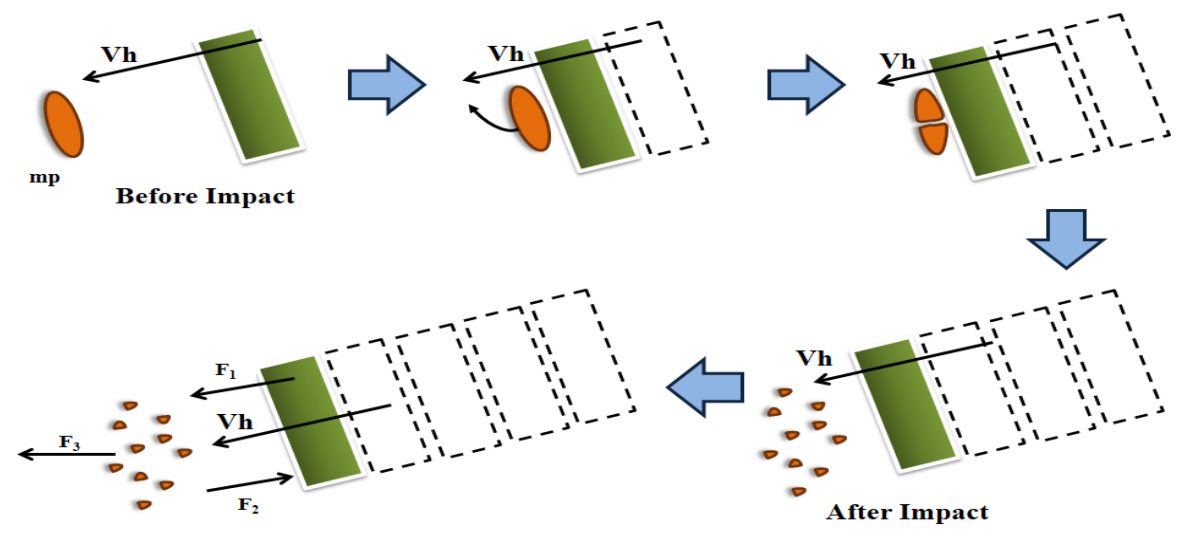

FIGURE 2. Illustration of of collision between impactor and material

results in the more collisions, in which the collisions happen both to reactor's wall and impactors (Figure 1(d) and Figure 1(e)). These continuous collisions permit the reduction of material sizes (Figure 1(f)).

Figure 2 shows the illustration during the collision between impactors and materials. The collision effects depend on the kinetic energy from impactor and the interchanged energy between impactor and material, giving impacts on the size reduction of material (Ibrahim et al. 2019)

Based on linear momentum before and after the collision, the hypothesis depends on the fact that the collision in the disk-milling apparatus between impactor and material is caused by the continuous forces $(F)$. The force induces object to move and to have different states of motion. The Newton second-law showed the motion followed (1):

$$
\sum F=0
$$

Adding the condition of forces as shown in Figure 2, namely $F_{1}, F_{2}$, and $F_{3}$ (corresponding to forces from impactor movement, material movement, and results of collision, respectively), followed (2):

$$
F_{1}-F_{2}=F_{3}
$$

Subsequently, the equation is re-written as (3):

$$
F_{1}-F_{2}-F_{3}=0
$$

Adding the definition of forces as a function of mass and acceleration, followed (4) or (5):

$$
m_{i} a_{i}=\left(m_{i}+m_{p}\right) a_{p}=0
$$

or,

$$
m_{i} a_{i}=\left(m_{i}+m_{p}\right) a=0
$$

Adding the definition of acceleration permits followed (6) then (7):

and,

$$
m_{i} \frac{d V_{i}}{d t}=\left(m_{i}+m_{p}\right) \frac{d V_{p}}{d t}=0
$$

$$
\frac{d}{d t}\left(m_{i} V_{i}-\left(m_{i}+m_{p}\right) V_{p}=0\right.
$$

Since $m_{i}+m_{p}=m$, above (7) is re-expressed as (8):

$$
m_{i} \frac{d V}{d t}=m a
$$

where $m_{i}, V_{i}$, and $a_{i}$ are the mass, the velocity, and the acceleration of impactor, respectively. $m_{p}, V_{p}$, and $a_{p}$ are the mass, the velocity, and the acceleration of material, respectively. $m$ and $a$ are the mass and the final acceleration of total mass interfered during the collision, respectively. The acceleration is detected by the movement of the collided material.

In addition to the force, the movement of the material must be considered based on its energy kinetic $\left(T_{0}\right)$. The energy kinetic of the material before impact is followed by (9):

$$
\frac{d}{d t} m_{i} V_{i}=m a=F
$$

Taking out the differential equation allows (10):

$$
\int m_{i} V_{i} d V_{i}=\frac{1}{2} m_{i} V_{i}^{2}
$$

whereas the final energy kinetic $\left(T_{F}\right)$ of the material is as followed (11):

$$
T_{F}=\frac{1}{2}\left(m_{i}+m_{p}\right) V_{s}^{2}
$$


Understanding the principle of total forces and momentum, the equation is expressed as (12) and (13):

$$
\Sigma F=\frac{d P}{d t}
$$

or,

$$
\Sigma F=\frac{d}{d t}(m v)
$$

where $P$ is the change in linear momentum; and $t$ is the change in time. The collision process that is accompanied by force causes the change in the momentum of the particles. Through the rearrangement of the Newton Second-Law equation, the changes of time interval in momentum is expressed by (14):

$$
d P=F \times d t
$$

Taking out the equation differential derives to (15) and to (16):

$$
\int_{t_{i}}^{t_{f}} d P=\int_{t_{i}}^{t_{f}} F \times d t
$$

and,

$$
P_{f}-P_{i}=F \times \Delta t
$$

Or, is written as (17):

$$
\Delta P=I
$$

The left side of (17) is the momentum equation $P$, and the right side is the impulse of collision $(I)$. This equation expresses that the momentum of two objects is the same, and the magnitude of the impulse is equal to the change in momentum. During the collision process in the diskmilling apparatus, materials collide with the impactor in a certain time interval. The impulse generated by number of colliding process $(n)$ during the time interval is defined by (18) or (19):

$$
I=n \times \Delta \mathrm{P}
$$

or,

$$
I=n \times m v
$$

Then, derived to (20):

$$
I=F \times \Delta t
$$

Equation (20) is re-expressed as (21):

$$
I=F \times \Delta t
$$

Substituting (18) to (21) results to (22):

$$
F \approx \frac{n m v}{\Delta t}
$$

where $n$ is the amount of collision; $m$ is the total mass interfered during collision; and $v$ is the velocity of impactor rotation.

These equations confirm that the force is equal to the number of collisions and the speed of the impactor but inversely proportional to the time. As a conclusion, the faster speed of the impactor results in the more number of impactor punching the material, showing the positive results in the force. Since the velocity itself is inverse proportional to the time, the shorter time gives positive results to the increasing value of force. Indeed, the greater force allows to the obtainment of more particles to be destroyed. In addition to the force itself, the opportunity in the collision is crucial. Indeed, this must be supported by the number of surface area of the impactor. The larger surface area leads to the more number of collision.

\section{MATERIALS AND METHODS}

Rice husk (purchased from Jaya Makmur Farm Shop, Bandung, Indonesia) was used as a model of size-reduced material. The rice husk was size-reduced using a homemade disk-milling apparatus. The disk-milling apparatus itself was re-designed from commercially apparatus (FCC-15; E-Scientific Laboratory, Bandung, Indonesia). The disk-milling apparatus was equipped with a motor $(1.1 \mathrm{~kW}$ at $2840 \mathrm{rpm}$ ) and a sieve filter (hole size of 0.6 $\mathrm{mm})$. The dimensions of disk-milling apparatus in length, width, and height are 230, 270, and $610 \mathrm{~mm}$, respectively. Different from other continuous disk-milling process, the present milling process was conducted in the batch process. All materials were put in the beginning, while the product was obtained continuously. Detailed illustration of the disk-milled apparatus is shown in Figure 3(a).

In short, the apparatus contains:

(i) Inlet (the part where the materials were put). The inlet was equipped with a valve that can be opened and closed manually to regulate the amount of material falling down into the reactor;

(ii) Reactor (the main component in the disk-milling apparatus where the milling process takes place inside it). This reactor section consists of disk plate components which are assembled with impactors. Rotating the disk plate results in collision and pressure on the material;

(iii) Sieve. The main aim of sieve is to determine the desired particle size;

(iv) Outlet. Milled products come out from the reactor through the outlet hole. This outlet is located under the reactor component on the disk mill.

To get precise analysis of mechanical impact, three impactors (i.e. triangle, cylinder, and cubes) were set and attached on the disk apparatus. Detailed shapes and dimensions of impactors are presented in Table 1. Detailed illustration of the disk-milling apparatus is shown in Figure 3(a). The disk rotation speeds were varied from 600 to $1500 \mathrm{rpm}$. 


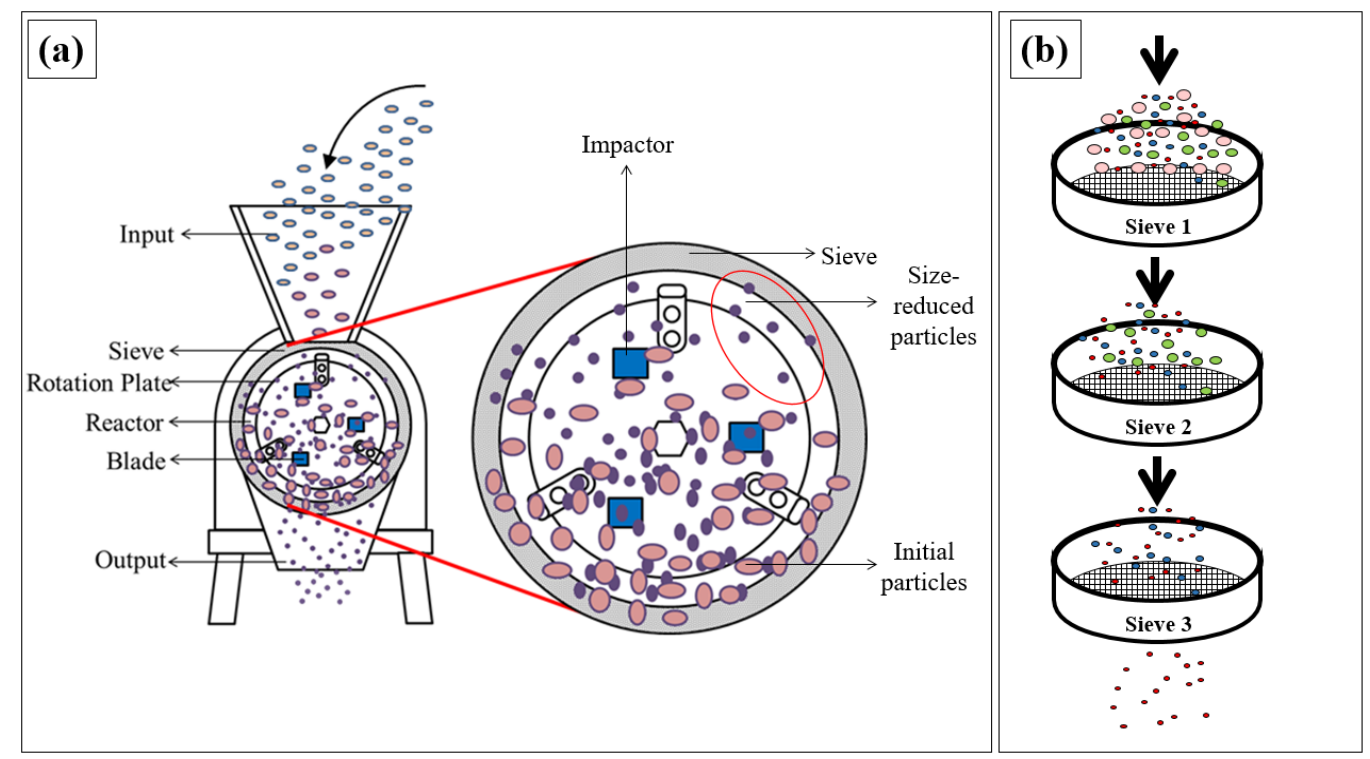

FIGURE 3. Detail of disk-milling apparatus and illustration of (a) milling, and (b) sieving process

TABLE 1. Detailed impactor shapes were used in the disk mill

\begin{tabular}{|c|c|c|c|}
\hline No & Impactor shape* & Model & Contact diameter $(\mathrm{cm})$ \\
\hline 1 & Large Triangle & & 1.73 \\
\hline 2 & Large Cylinder & & 2 \\
\hline 3 & Large Cube & & 2.82 \\
\hline 4 & Small Cube & & 2.12 \\
\hline
\end{tabular}

*Note: Impactor number 1, 2, and 3 were used in the evaluation of controlling mechanical impact. Impactor number 3 and 4 were used in the impactor optimization

Regarding the dimension of impactor, we analyzed the use of contact diameter. The contact diameter is the diameter of an irregular shape that is nearly equal to the diameter of the cylinder shape for giving the same pressure and resistance during the milling process. This diameter is calculated based on the maximum length in 
the shape that is potentially creating impact to the object. The cylinder shape is calculated using its diameter since it results in maximum impacts in making contact with the material. For the case of cubes, the contact diameter is the length diagonal.

Several characterizations were done:

(i) for chemical structural characterization, a Fourier transform infrared (FTIR; FTIR-4600, Jasco Corp., Japan) was used.

(ii) for material morphological characterization, a Scanning Electron Microscopy (SEM; JSM-6360LA; JEOL Ltd., Japan) and a Digital Microscope (BXAW-AX-BC, China) were used.

To get the particle size distribution, the disk-milled product was analyzed using the test sieve (PT Rumah Publikasi Indonesia, Indonesia) with various hole sizes of 2000, 1000, 595, 530, 297, 250, 177, 149, 125, 105, 99, $88,74,58$, and $48 \mu \mathrm{m}$ (Figure 3(b)). The disk-milled rice husk materials were classified based on the test sieve. The total weight of samples and the mass of each test sieve categories were weighed using a precise digital scale with an accuracy of $0.001 \mathrm{~kg}$. The mass percentage distribution of each fraction was determined by dividing the fraction's mass with the total mass of the output product. Then, the mass percentage distribution was then used for calculating the particle size $\left(D_{\text {ave }}\right)$.

In addition, to support the mechanical impact, measurement of the specific energy consumption was done. Electrical power consumption was calculated from the direct measured electric current and voltage values (Dabbour et al. 2015) followed (23):

$$
E p=\frac{\sqrt{3} \cdot i \cdot \text { Volt } \cdot \eta \cdot \cos \theta}{1000}
$$

where $E p$ is the electrical power $(\mathrm{kW}) ; i$ is the electric current (A); Volt is the electrical voltage $(\mathrm{V}) ; \eta$ is the mechanical efficiency assumed to be 0.95 ; and $\cos \theta$ is the power factors being equal to (0.84). The equation was then derived into the specific energy consumption $(\mathrm{kJ} /$ $\mathrm{kg}$ ) by dividing $E p$ with mass productivity. All electrical measurements were done using commercially available equipment attached in the disk-milling apparatus. The $E p$ was the used to predict the milling ability index $(G I)$ that has direct correlation to the mechanical impact using the following (24) (Dabbour et al. 2015):

$$
G I=C_{D} \cdot E p \cdot \rho \cdot D_{\text {ave }}
$$

where $\rho$ is the main density of the material (about 600 $\mathrm{kg} / \mathrm{m}^{3}$ ) and $C_{D}$ is the coefficient. Assuming the mass productivity is ideal, the value of $C_{D}$ is 0.1667 .

\section{RESULTS AND DISCUSSION}

\section{PHYSICOCHEMICAL PROPERTIES OF RICE HUSK BEFORE AND AFTER THE DISK-MILLING PROCESS}

Figure 4 shows the images of rice husk particles before and after the milling process. The initial rice husk particles have sizes of about $8 \mathrm{~mm}(8000 \mu \mathrm{m})($ Figure $4(\mathrm{a}))$. After the milling process, there is a reduction of particle size (Figure 4(b)). The final particle sizes were mostly in the range of 73-1000 $\mu \mathrm{m}$. Detailed image of rice husk particles after milling process was confirmed by the analysis using the SEM measurement (Figure 4(c)). To confirm the particle size, Figure 4(d) shows the particle size distribution based on sieve test measurement. The results showed that the mean particle size was $347 \mu \mathrm{m}$.
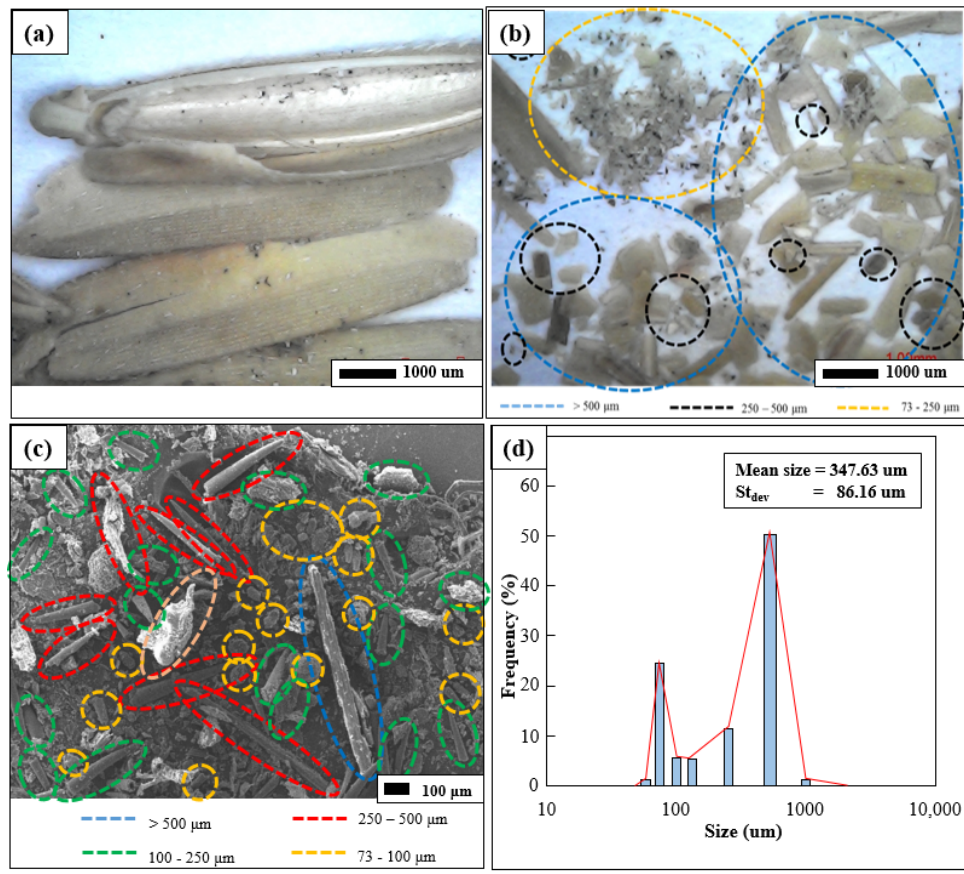

FIGURE 4. Photograph images of rice husk (a) before, and (b) after disk-milling process, (c) SEM image of disk-milled rice husk, and (d) particle size distribution. Sample was done using cubes impactor at speed of $1500 \mathrm{rpm}$ 
Figure 5 shows the FTIR results of rice husk before and after the milling process. Both FTIR spectra have the same peaks at specific wavelengths with different transmittances. Rice husk after the milling process has a higher intensity than that before the milling process. The increases in intensities were due to the treatment of the milling process which was able to destroy the outer structure of the rice husk (i.e. cellulose, hemicellulose, and lignin; see dashed area in Figure 5) (Saudi et al. 2015).

Several peaks were detected. The peak at 862.75 $\mathrm{cm}^{-1}$ related to the vibration stretching of the siloxane group. The peak at $1057.04 \mathrm{~cm}^{-1}$ corresponds to the Si-O bond. The peak at $1633.34 \mathrm{~cm}^{-1}$ is assigned to the bending vibration of $-\mathrm{OH}$ groups. Meanwhile, the peaks at 3200.00 and $3303.73 \mathrm{~cm}^{-1}$ are attributed to the stretching vibration of $-\mathrm{OH}$ groups. The peaks at 2852.00 and $2926.06 \mathrm{~cm}^{-1}$ are assigned, respectively, to the symmetric and asymmetric stretching vibration of the aliphatic $\mathrm{C}-\mathrm{H}$ bonds in $-\mathrm{CH}_{3}$ and $-\mathrm{CH}_{2}$ groups in the main component of rice husk (related with structure of cellulose, hemicellulose, and lignin).

To confirm effects of milling process on the chemical structure, Figure 6 presents the FTIR analysis of milled rice husk with various sizes. The results showed identical FTIR peaks and patterns. The change in intensity was found for particles with smaller sizes, in which this is due to the existence of physically adsorbed water.

The peak positions of FTIR profiles agree with the standard rice husk component. The FTIR results exhibited no change in chemical structure after the milling process. Milling process influences only size reduction (Nandiyanto et al. 2019; Saudi et al. 2015).

\section{OPTIMIZATION OF MASS IN THE MILLING PROCESS}

Table 2 shows the effect of mass input on the effectiveness of the disk-milling process. Effect of mass rice husk input is done only using the triangle-shaped impactor (as a reference for optimizing other types of impactors). The use of other types of impactors in the same amount of rice husk mass will create the same conditions for getting either successful or failure milling process.

To optimize rice husk mass for the milling process, the mass of rice husk mass into the disk-milling apparatus was varied (i.e. 8,12 , and $14 \mathrm{~g}$ ). The milling process was carried out under a certain speed and milling time. To determine the successful milling process, we classified into successful and failure based on the yield.

The best milling process can be obtained when the process was done in the optimum mass capacity. When the capacity of the rice husk is more than the optimum condition (overload), the failure milling was obtained. Problems were found in the disk rotation, in which the rice husk filled the empty space between disk and rotor, disturbed and blocked the rotation process of disk. Thus, the rotating disk does not have enough energy to make collision with the materials. On the contrary, when the capacity was less than the optimal capacity, the milling process was ineffective since the impactor does not optimally conduct many collisions to the rice husk particles (Yadav et al. 2012).

Figure 7 shows the energy consumption when using various mass inputs and disk rotation speeds. The results showed that the total energy consumption increased with increasing the rotation speeds and the milling time. The investigation was done by calculating the amount of energy compared to the mass of the rice husk added into the system.

Figure 7(a) and Figure 7(b) is the analysis of energy when using mass of 8 and $12 \mathrm{~g}$, respectively. The results presented that the use of less mass is inefficient in the utilization of energy. This is because the disk-milling process itself has a minimum required energy to spin the disk. Thus, optimization of the added mass is important to be conducted.

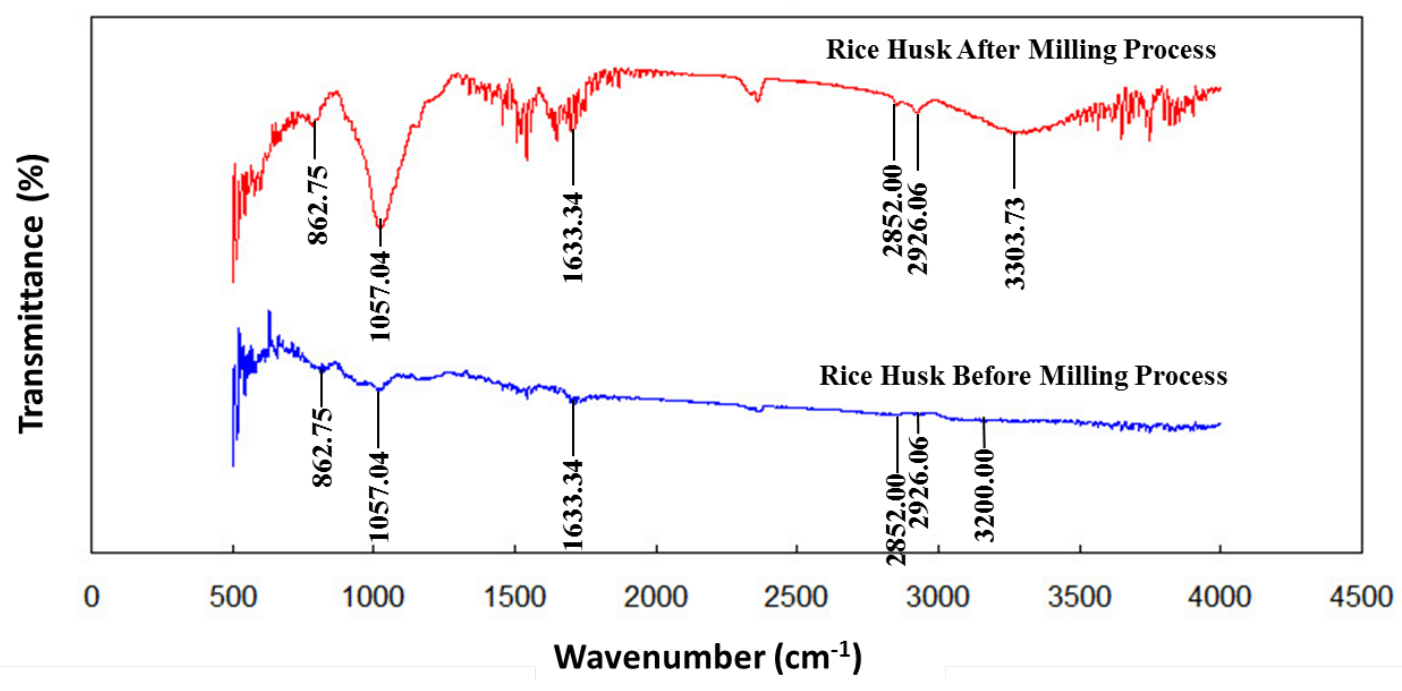

FIGURE 5. FTIR analysis of the rice husk before and after milling process 


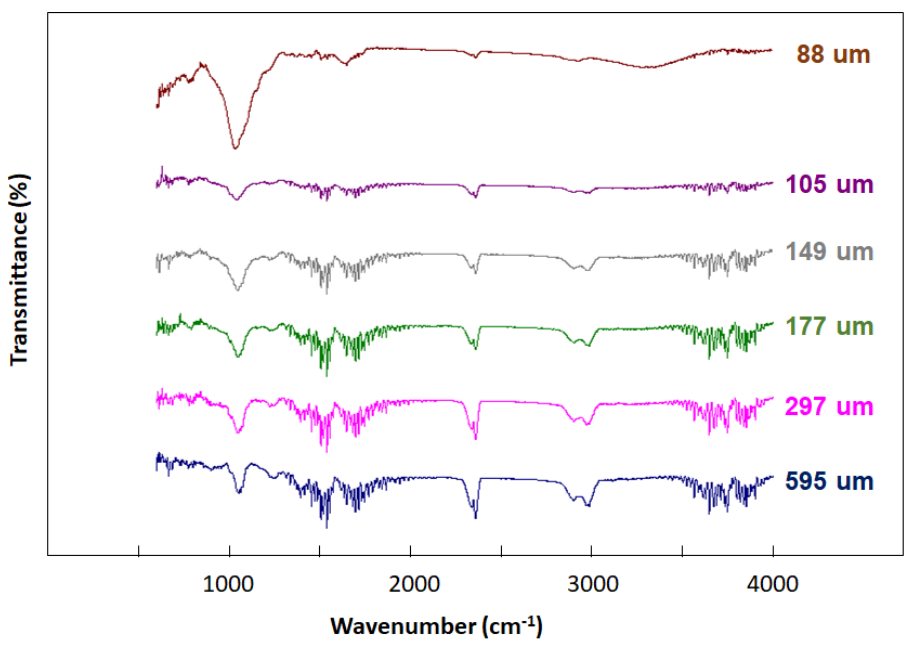

FIGURE 6. FTIR analysis of the milled rice husk with various sizes

TABLE 2. Effect of additional inlet mass on the effectiveness of disk mill

\begin{tabular}{ccccc}
\hline No & Input Mass $(\mathrm{g})$ & Impactor shape & Yield & Conclusion \\
\hline 1 & 8.00 & Triangle & Not good & Fail \\
2 & 12.00 & Triangle & Excellent & Success \\
3 & 14.00 & Triangle & Not success & Fail \\
\hline
\end{tabular}
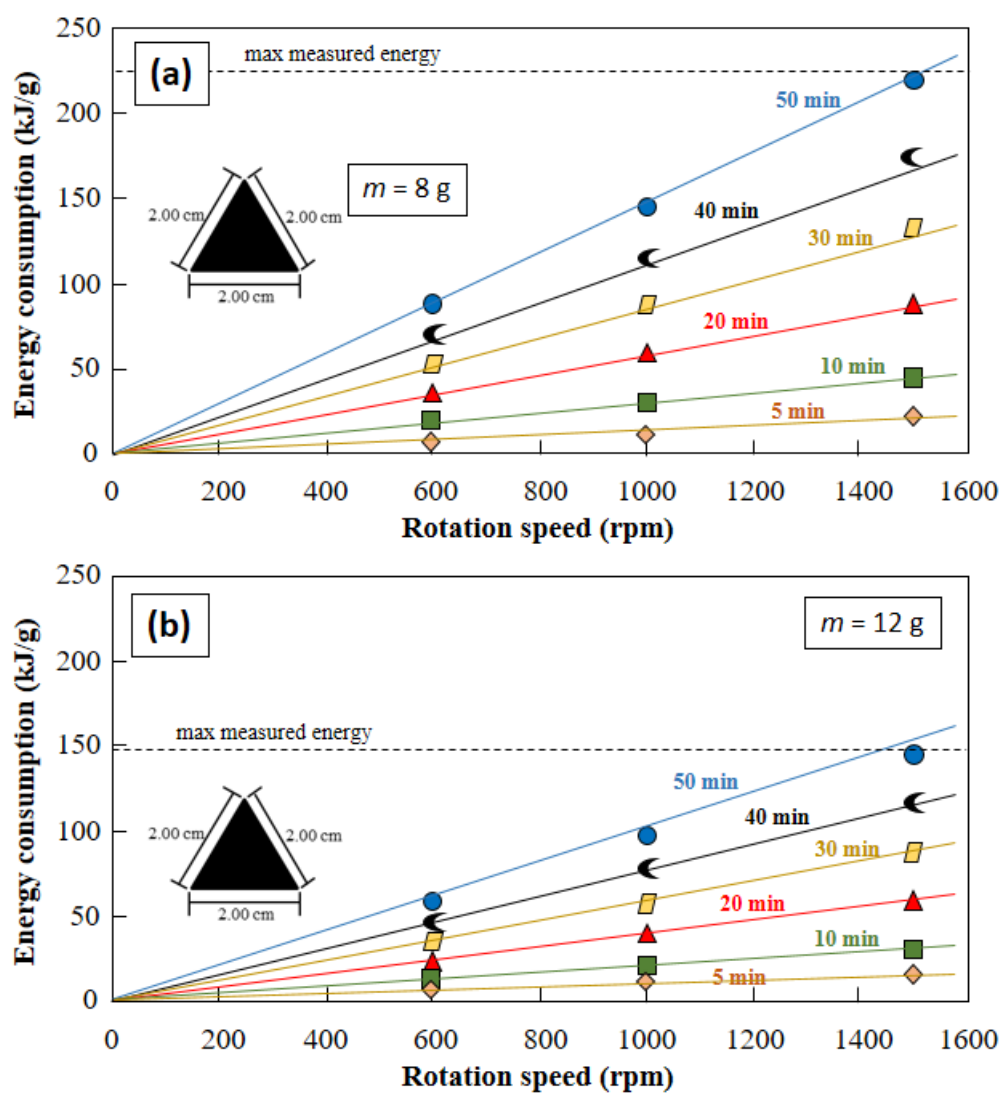

FIGURE 7. Energy consumption for (a) 8.00, and (b) $12.00 \mathrm{~g}$ of rice husk under triangle disk rotation speeds. The process using large triangle impactors, in which the dimension of the impactor is shown as the paneled image in the figure 


\section{OPTIMIZATION OF MILLING TIME}

Optimization of the milling time aims to investigate the obtainment of optimum condition for getting the best particle size distribution and the product yields. This information is important, as presented in Figure 6, since the milling time has a direct correlation to the energy consumption.

Figure 8 shows the particle size distribution based on various milling time (i.e. 5, 10, 20, 30, 40, and $50 \mathrm{~min}$ ) at a disk rotational speed of $1500 \mathrm{rpm}$. The yield of the product was also examined (insert table in Figure 8).

The initial product after 5 min of milling has low peak intensity in the particle size distribution. The small number of product yields were also obtained. The longer milling time resulted in the higher intensities of particle size distribution peak. This has a good correlation to the increases in the number of product yields (see main peak). The mean sizes of the rice husk were reduced to a range of 250 and $1000 \mu \mathrm{m}$. Appearance of particles with sizes in the range of between 74 and $99 \mu \mathrm{m}$ was found (as shown in the sub-peak area in Figure 8).

The longer milling process from 10 to $40 \mathrm{~min}$ gives more collision process, making more destruction of materials and resulting smaller particles (sizes in the range of 250 and $1000 \mu \mathrm{m}$ and the appearance of higher intensities in the sub peak). This is in line with Li et al. (2018) that increasing milling time can increase product yields and reduce particle size of materials. Further increases in time allowed to the obtainment of sub peak (sizes of 48 - $74 \mu \mathrm{m}$ ).

After 50 min of milling process, sub-peak intensity started to disappear, informing that the longer milling time did not show significant changes in the size-reduction process. The main reason for this ineffective process is because of the possibility in the re-aggregation of particles, in which this is well explained in literature (Tahara et al. 2014).

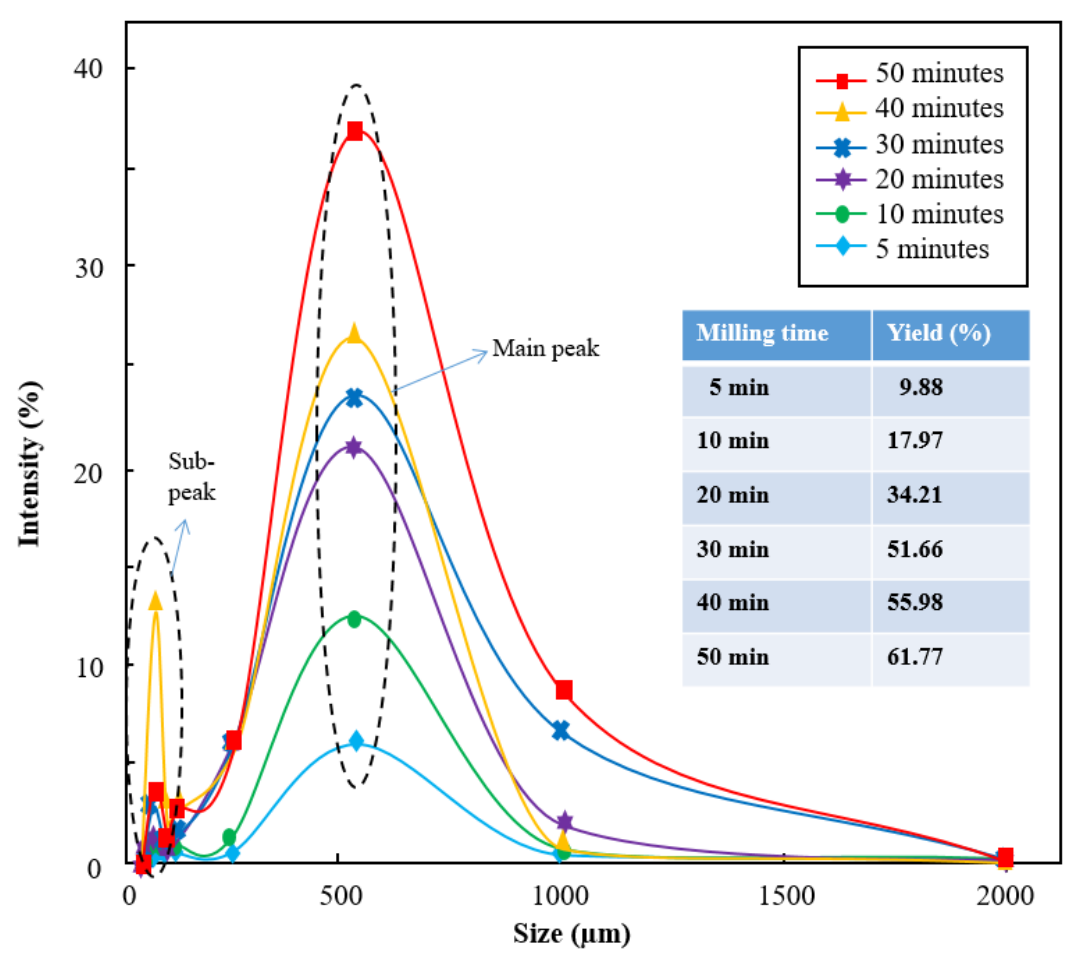

FIGURE 8. Effect of milling time on reducing the particle size and product yields.

The milling process was done using triangle impactor

\section{CONTROLLING MECHANICAL IMPACT IN DISK MILL}

Several ways to adjust the mechanical impact during the milling process: The geometrical shape of the impactor, the size and number of the impactor, the materials used for milling media, the disk rotational speed, milling time, physicochemical characteristics of the material destroyed, and milling temperature (Schneider et al. 2009; Tahara et al. 2014). This study limited to the evaluation of various impactor shapes and disk rotation speeds to arrange the number of collisions. 
Two types of impactors with the same shapes (namely large and small cubes) were used, and the process was done under various rotation speeds. Both cube shapes have different number of surface area. The results of the disk impactor and rotation speed optimization are shown in Figure 9(a) and Figure 9(b), corresponding to large and small cubes, respectively.

The curve in Figure 9(a) has a higher intensity than that in Figure 9(b), demonstrating the more effective process in reducing rice husk particle size. Further, sub peak appeared in the curve in Figure 9(a), informing the obtainment of size of tens micrometers. On the contrary, the product from small cube impactor have some larger particles in the product (most left dashed area in Figure 9(b); reaching $5 \%$ of the total mass), confirming that small cubes (Figure 9(a)) is less effective in decreasing size compared to the process using large cubes (Figure 9(a)). The large cube is more effective since it promotes larger contact diameter of the impactor, leading to the more number of collisions. In addition, we also found that the disk rotation speed is also very influential in reducing size for all cases.
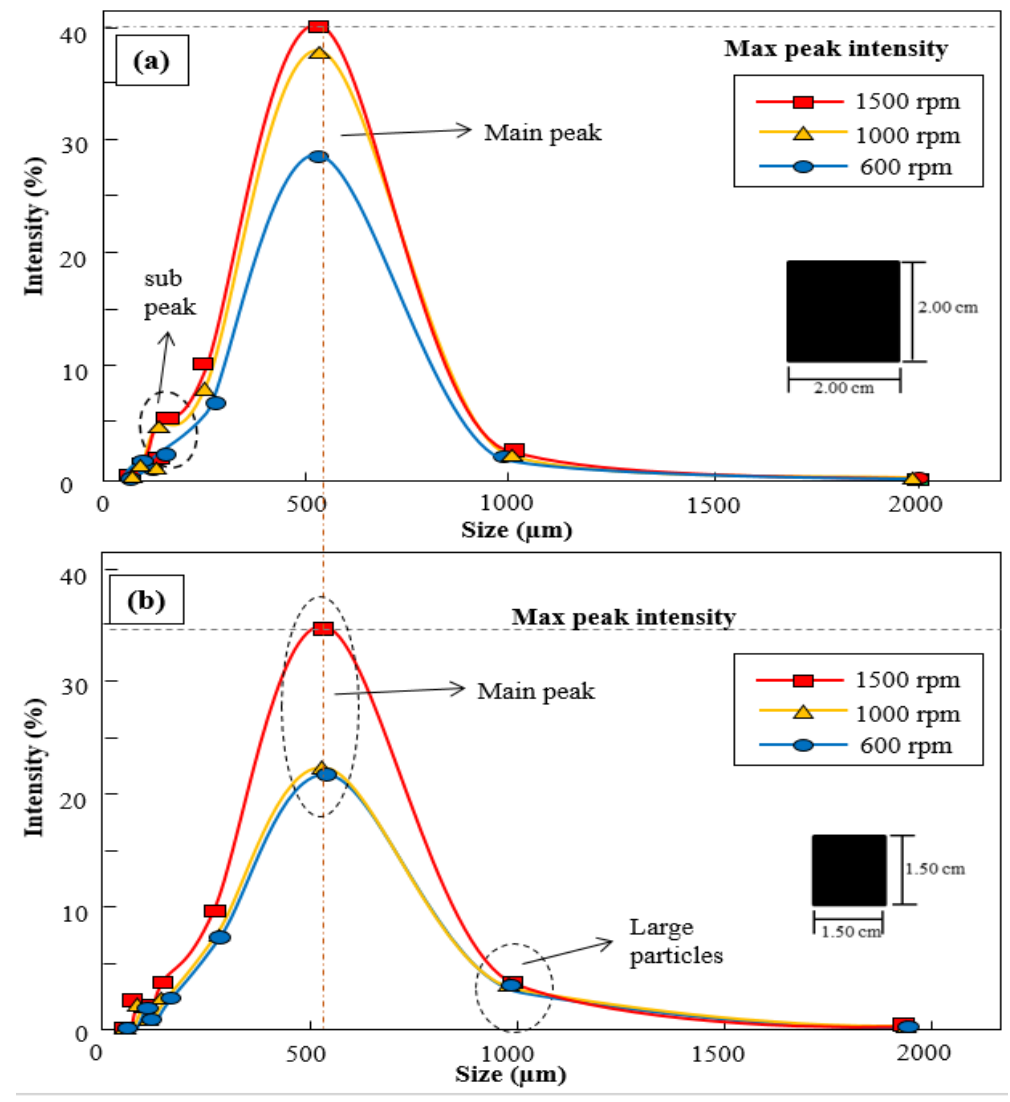

FIGURE 9. Effect of impactor types (i.e. (a) large, and (b) small cubes) on particle size distribution under various rotation speeds in the milling process

Figure 10 shows the results of the particle size distribution using various milling shapes (i.e. cylinder and triangle) and disk rotation speeds (i.e. 600, 1000, and 1500 $\mathrm{rpm})$. Based on the analysis of mass, milling time, and impactor shapes, experiments were done under a constant optimum mass of materials (12 g) and milling time (40 min). Overall, all curves have similar form. However, the main different from one to the other parameter is the intensity, informing that the main impacts are directly to the particle size. The disk rotation speed at $1500 \mathrm{rpm}$ for all types of impactors is the best, confirmed by the highest number of particle size distribution and the highest product yield. The trends in the intensities were then followed by the disk rotation speed of 1000 and $600 \mathrm{rpm}$.

All peaks have broad size distribution curves. The characteristics of the broad curves showed that the most of the rice husk materials after the milling process have sizes in the range of 250 and $1000 \mu \mathrm{m}$. The use of impactors 
with cubes (Figure 10(a)) and triangles (Figure 10(b)) allowed the appearance of sub peaks, informing that both types of impactors are capable of producing products with smaller and finer in sizes compared to the use of cylindertyped impactor. The sub-peak has a range of between 74 and $99 \mu \mathrm{m}$.
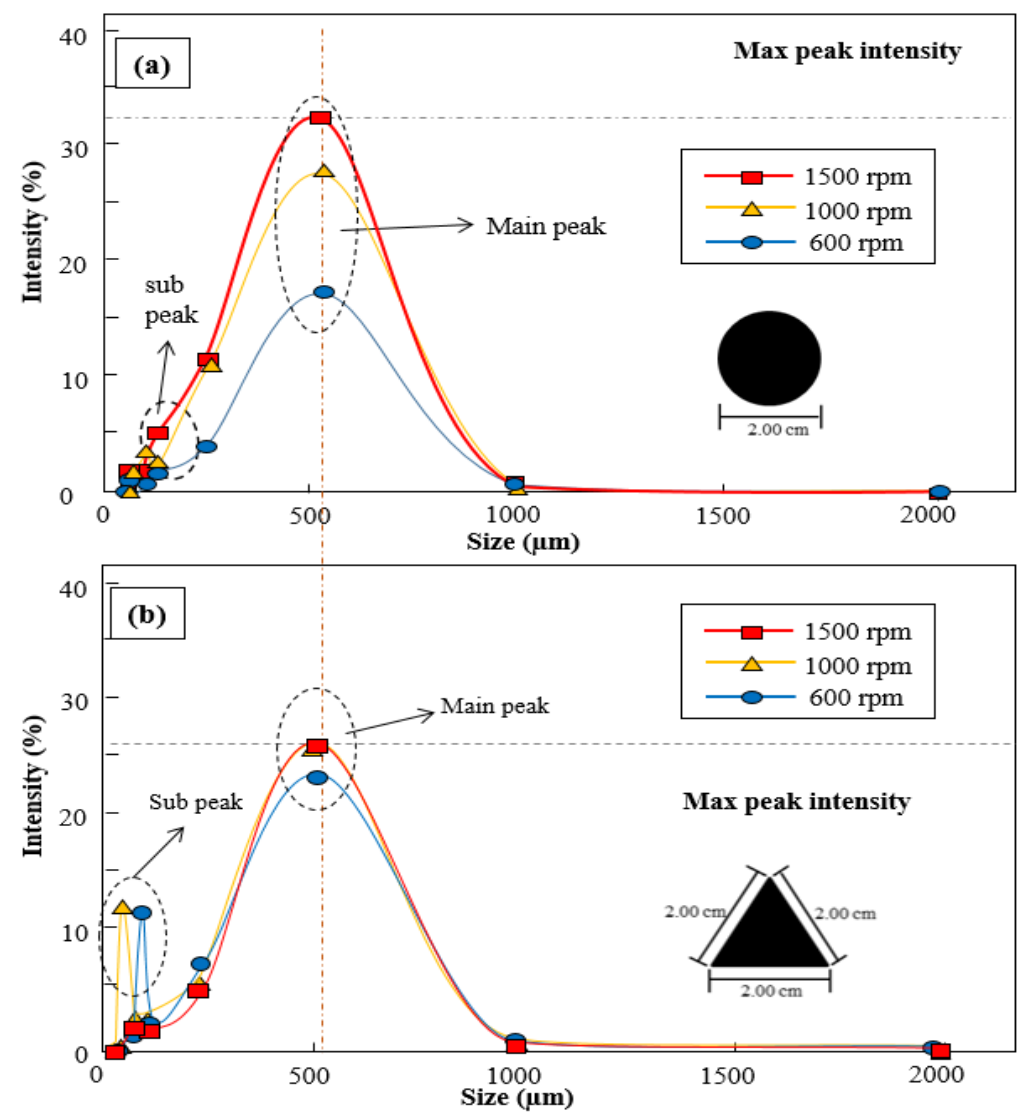

FIGURE 10. Particle size distribution of disk-milling process using (a) cylinders, and (b) triangles

To clarify the effect of impactor shapes and disk milling speeds on the effectiveness of the disk-milling process, Figure 11 shows the curves for the correlation of final particle size and energy for the milling ability.

As shown in Figure 11(a), the smaller particles were obtained when the process was conducted by higher rotation speeds. However, too high rotational speeds seemed to have no impact on the particle size. The main influential parameters are the impactor shapes, reducing sizes of down to $300 \mu \mathrm{m}$.

Although the higher rotational speed during the milling process gives impacts on making size reduction (relating to the stronger pressing and hitting frequency), it can cause high wear of the impactor, leading to high contamination, excessive heating, and lower powder yields.
Figure 11(b) is the effect of these parameters on the energy as the function of milling ability, obtained using (24). This energy is an important indicator for gaining the relationship between the required energy of grinding and the level of destruction during milling process. The results indicated that it ranged from 30 to $80 \mathrm{MJ} /$ $\mathrm{m}^{2}$. The results confirmed that the milling ability index increased with increasing rotation speeds. The effect of the impactor shapes is clearly observed. These curves confirmed that rotation speeds and impactor shapes are the main parameters that can adjust the mechanical impact in the disk milling process. The explanation for the effect of rotation speeds and impactor shapes are in the following.

Regarding the impactor shapes, they relate to the number of surface area of the impactor. The larger surface area increases the number of colliding (between impactor 
and materials). This is the main reason when larger cubes allow better milling process than smaller cubes (Figure 9).

When using impactor with almost the same dimension but different shapes, different results were obtained (Figure 11), which is due to the existence of contact diameter. Contact diameter is the longest size from the impactor area describing the possibility contact between impactor and materials. Contact diameter for triangle, cylinder, and cube are $1.73 ; 2.00$; and $2.82 \mathrm{~cm}$ (Table 1). This is in line with the sequence for the best to the worst types of impactors that were triangle, cylinder, and cube, respectively. The smaller contact diameter gave impacts to the more effective milling process. The impactors with smaller contact diameters have sharper surfaces for hitting and pressing particles. Thus, the contact particles can make more severely damaged, resulting smaller particles to be more producible (Alves et al. 2013).

In the case of the disk rotation speed, experiments confirmed that $1500 \mathrm{rpm}$ is the most optimal disk rotation speed to produce smaller and finer sizes with high product yields. The main reason is because the faster disk rotation allows the more number of collisions between impactors and materials. Higher speed also gives higher values of impulse since less contact time between impactor and material, making the higher mechanical energy impact applied to the materials.
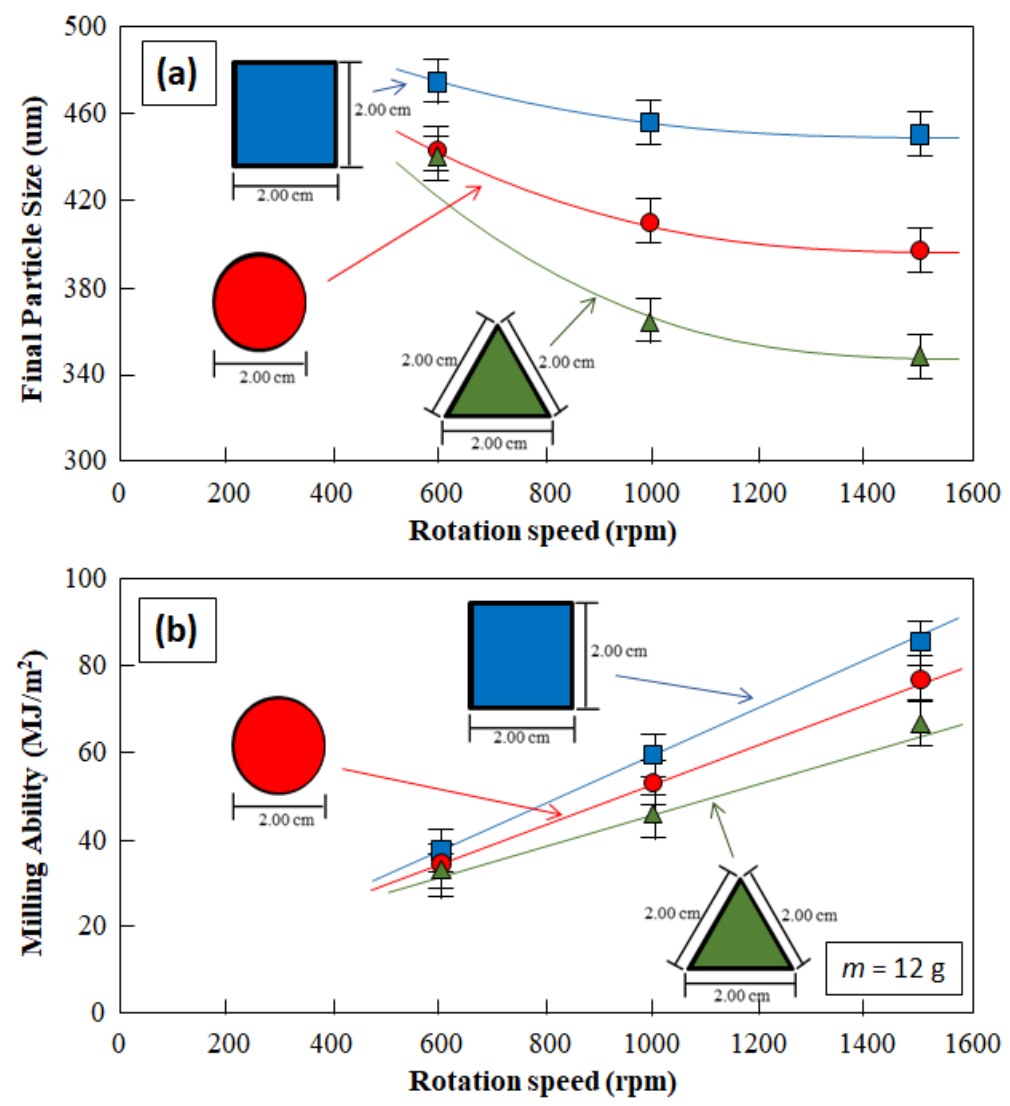

FIGURE 11. Effect of impactor shapes and rotation speeds on the (a) particle size, and (b) energy for milling ability

\section{CONCLUSION}

The effect of impactor size and shapes as well as disk rotation speed on size reduction has been evaluated for understanding the mechanical impact in the disk-milling process. Rice husk was selected as a model of size-reduced material. Experimental results showed that the collision profiles can be controlled by varying the impactor shapes (i.e. triangle, cylinder, and cubes) and disk rotation speeds. Different types of impactor shapes and disk rotation speeds have a great influence for changing collision 
profiles, in turn giving impacts on the final particle size. The most effective process condition for reducing size of rice husk was obtained when using triangle impactors with a disk rotation speed of $1500 \mathrm{rpm}$, which can allow the mean final particle sizes of down to $74 \mu \mathrm{m}$. Different types of impactors gave impacts to the contact diameter and area for more particles to be collided, whereas disk rotation speed gave possibilities of more collision number (between rice husk and impactor) and more impact from the collision (due to less time contact during collision).

\section{ACKNOWLEDGEMENTS}

This study acknowledged RISTEK DIKTI for Grantin-aid Penelitian Terapan Unggulan Perguruan Tinggi (PTUPT).

\section{REFERENCES}

Alves, A.K., Bergmann, C.P. \& Berutti, F.A. 2013. Novel Synthesis and Characterization of Nanostructured Materials. Berlin: Springer.

Amankwah, R., Nartey, R., Al-Hassan, S. \& Ofori-Sarpong, G. 2010. The effect of comminution equipment on gravity gold recovery in small-scale mining operations. International Journal of Environment and Pollution 41(3-4): 316-325.

Ariwibowo, D., Mrihardjono, J. \& Handayani, S.U. 2018. Energy consumption characteristics of disc mill to produce cob flour. Advanced Science Letters 24(12): 9589-9591.

Dabbour, M., Bahnasawy, A., Ali, S. \& El-Haddad, Z. 2015. Grinding parameters and their effects on the quality of corn for feed processing. Journal of Food Processing and Technology 6(9): 1.

Dirgantari, P.D., Nandiyanto, A.B.D. \& Machmud, A. 2019. Development strategy of earthworms nanoparticle products using ball mill methods in Indonesia. Journal of Engineering Science and Technolog 14(2): 589-598.

Gorrasi, G. \& Sorrentino, A. 2015. Mechanical milling as a technology to produce structural and functional bionanocomposites. Green Chemistry 17(5): 2610-2625.

Ibrahim, M., Omran, M. \& Abd EL-Rhman, E. 2019. Design and evaluation of crushing hammer mill. Misr Journal of Agricultural Engineering 36(1): 1-24.

Jayasundara, C.T., Yang, R., Yu, A. \& Rubenstein, J. 2010. Effects of disc rotation speed and media loading on particle flow and grinding performance in a horizontal stirred mill. International Journal of Mineral Processing 96(1-4): 27-35.

Kumar, C.S., Malleshi, N. \& Bhattacharya, S. 2008. A comparison of selected quality attributes of flours: Effects of dry and wet grinding methods. International Journal of Food Properties 11(4): 845-857.

Li, X., Kokawa, M. \& Kitamura, Y. 2018. Influence of micro wet milling parameters on the processing of Komatsuna (Brassica rapa var. perviridis) juice with rich phosphatidic acid. Journal of Food Engineering 217: 50-57.

Meenakshi, S., Sundaram, C.S. \& Sukumar, R. 2008. Enhanced fluoride sorption by mechanochemically activated kaolinites. Journal of Hazardous Materials 153(1-2): 164 172.

Nandiyanto, A.B.D. 2019. Amorphous porous carbon microparticles from Lumbricus rubellus. Journal of Engineering Research 7: 13-20.

Nandiyanto, A.B.D., Ragadhita, R., Oktiani, R., Sukmafitri, A. \& Fiandini, M. 2020. Crystallite sizes on the photocatalytic performance of submicron $\mathrm{WO}_{3}$ particles. Journal of Engineering Science and Technology 15(3): 1506-1519.

Nandiyanto, A.B.D., Oktiani, R. \& Ragadhita, R. 2019. How to read and interpret FTIR spectroscope of organic material. Indonesian Journal of Science and Technology 4(1): 97-118.

Nandiyanto, A.B.D., Andika, R., Aziz, M. \& Riza, L.S. 2018a Working volume and milling time on the product size/ morphology, product yield, and electricity consumption in the ball-milling process of organic material. Indonesian Journal of Science and Technology 3(2): 82-94.

Nandiyanto, A.B.D., Oktiani, R., Zaen, R., Danuwijaya, A.A., Abdullah, A.G. \& Haristiani, N. 2018b. Evaluation of ball-milling process for the production of carbon particles from rice straw waste. Pertanika Journal of Science and Technology 26(3): 1373-1382. C

Nandiyanto, A.B.D., Zaen, R. \& Oktiani, R. 2018c. Working volume in high-energy ball-milling process on breakage characteristics and adsorption performance of rice straw ash. Arabian Journal for Science and Engineering 43(11): 6057-6066.

Nandiyanto, A.B.D., Putra, Z.A., Andika, R., Bilad, M.R., Kurniawan, T., Zulhijah, R. \& Hamidah, I. 2017. Porous activated carbon particles from rice straw waste and their adsorption properties. Journal of Engineering Science and Technology 12: 1-11.

Odo, E., Britton, D., Gonfa, G. \& Harting, M. 2012. Structure and characterization of silicon nanoparticles produced using a vibratory disc mill. The African Review of Physics 7: 0007.

Rice, A., Tait, J. \& Anderson, M. 2009. Use of tungsten carbide disc-mill in geochemistry: No evidence of contamination. EGUGA 9350.

Sasaki, K., Okamoto, M., Shirai, T., Tsuge, Y., Fujino, A., Sasaki, D., Morita, M., Matsuda, F., Kikuchi, J. \& Kondo, A. 2016. Toward the complete utilization of rice straw: Methane fermentation and lignin recovery by a combinational process involving mechanical milling, supporting material and nanofiltration. Bioresource Technology 216: 830-837.

Saudi, H., Salem, S., Mohammad, S., Mostafa, A. \& Hassaan, M. 2015. Utilization of pure silica extracted from rice husk and FTIR structural analysis of the prepared glasses. Semiconductors 24: 25.

Schneider, F., Stolle, A., Ondruschka, B. \& Hopf, H. 2009. The Suzuki-Miyaura reaction under mechanochemical conditions. Organic Process Research and Development 13(1): 44-48.

Sukmafitri, A., Ragadhita, R. \& Nandiyanto, A.B.D. 2020. Disk rotation speed and diameter of impactor in disk mill on particle size distribution from rice husk. Journal of Engineering Science and Technology 15(3): 1698-1704.

Tahara, T., Imajyo, Y., Nandiyanto, A.B.D., Ogi, T., Iwaki, T. \& Okuyama, K. 2014. Low-energy bead-milling dispersions of 
rod-type titania nanoparticles and their optical properties. Advanced Powder Technology 25(5): 1492-1499.

Uzun, R.O. \& Durmuş, H. 2016. Effect of mill type on morphology of AA6013 aluminium powder. Matéria (Rio de Janeiro) 21(3): 647-654.

Womac, A.R., Igathinathane, C., Bitra, P., Miu, P., Yang, T., Sokhansanj, S. \& Narayan, S. 2007. Biomass Pre-Processing Size Reduction with Instrumented Mills. ASABE Meeting Presentation. American Society of Agricultural and Biological Engineers.

Yadav, T.P., Yadav, R.M. \& Singh, D.P. 2012. Mechanical milling: A top down approach for the synthesis of nanomaterials and nanocomposites. Nanoscience and Nanotechnology 2(3): $22-48$.

Asep Bayu Dani Nandiyanto*, Risti Ragadhita \& Ajeng Sukmafitri

Departemen Kimia

Universitas Pendidikan Indonesia

Bandung

Indonesia
Muhammad Roil Bilad

Chemical Engineering Department

Universiti Teknologi Petronas

31750 Tronoh, Perak Darul Ridzuan

Malaysia

Muhammad Aziz

Institute of Industrial Science

The University of Tokyo

Tokyo, 153-8505

Japan

Jumril Yunas

Institute of Microengineering and Nanoelectronics (IMEN)

Universiti Kebangsaan Malaysia

43600 UKM Bangi, Selangor Darul Ehsan

Malaysia

*Corresponding author; email: nandiyanto@upi.edu

Received: 20 July 2020

Accepted: 8 August 2020 